Teresa Czerwińska*

\title{
INSTRUMENTY POLITYKI \\ MIKRO- I MAKROOSTROŻNOŚCIOWEJ W SEKTORZE UBEZPIECZEŃ
}

\section{Wprowadzenie}

Pierwotnie regulacje ostrożnościowe w sektorze finansowym miały na celu egzekwowanie dyscypliny rynkowej. Ingerencja w mechanizm rynkowy polegająca na ograniczeniu konkurencji miała na celu przede wszystkim prewencję upadłości instytucji oraz egzekwowanie ostrożnego podejścia w zakresie zarządzania ryzykiem, co miałoby efekt także prewencyjny w kontekście kryzysów gospodarczych ${ }^{1}$. O ile same przesłanki wprowadzania regulacji ostrożnościowych w sektorze ubezpieczeń - ze względu na jego szczególną pozycję w systemie finansowym gospodarki - nie wzbudzają kontrowersji, to przedmiotem żywej dyskusji, zwłaszcza w ostatnim czasie, jest zakres ich ingerencji w praktyki rynkowe prywatnych instytucji finansowych. „Uspołecznianie się” strat prywatnych instytucji finansowych wskutek globalnego kryzysu, czyli przenoszenie skutków moral hazard na społeczeństwo², stawia zagadnienie zasadności stosowania instrumentów ostrożnościowych w zupełnie nowym świetle. W sektorze ubezpieczeń dotychczas w zasadzie dominowało podejście mikroostrożnościowe. Instytucje ubezpieczeniowe zaliczane są do kategorii podmiotów o relatywnie niskim w relacji do banków ryzyku systemowym ${ }^{3}$. Katalizatorem podejścia makroostrożnościowego do regulacji nadzorczych w sektorze ubezpieczeniowym

* Uniwersytet Warszawski, Wydział Zarządzania.

1 Zob. E.N. White, Lessons From The History Of Bank Examination And Supervision in the United States, 1863-2008, w: Financial Market Regulation in the Wake of Financial Crises: The Historical Experience, red. A. Gigliobianco, G. Toniolo, "Banca d'Italia" 2009, series No. 1, s. 19 i nast.

2 N. Roubini, S. Mihm, Ekonomia kryzysu, Wolters Kluwer, Warszawa 2011, s. 77.

3 Zob. Systemic Risk in Insurance, 2010; Insurance and Financial Stability, 2011; J.H. Fitzpatrick, Cross industry analysis 28 G-SIBs vs. 28 Insurers - Comparison of systemic risk indicators, The Geneva Association, February 2013; H. Chen., J.D. Cummins, S. Krupa, S. Viswanathan, M.A. Weiss, Systemic Risk and the Interconnectedness between Banks and Insurers: an Econometric Analysis, "The Journal of Risk and Insurance" 2013, Vol. 81, No. 3, s. 623-652. 
stały się wydarzenia związane z ostatnim kryzysem, które pokazały, że zachowania indywidualnych podmiotów nie są optymalne z punktu widzenia stabilności finansowej w szerszej perspektywie.

Celem opracowania jest analiza kluczowych cech podejścia mikro- i makroostrożnościowego do kwestii regulacji nadzorczych w sektorze ubezpieczeń. Przedstawiono systematykę instrumentarium polityki makro- i mikroostrożnościowej oraz zidentyfikowano kierunki i cele jej oddziaływania w sektorze ubezpieczeń.

\section{Dwa wymiary polityki ostrożnościowej w sektorze ubezpieczeń}

Polityka ostrożnościowa w sektorze finansowym powinna być rozumiana jako całokształt świadomych, wewnętrznie spójnych działań, polegających na rozpoznaniu potencjału, wyznaczeniu celów i preferencji oraz doborze odpowiedniego instrumentarium (metod, środków i sposobów) ich realizacji. Warto podkreślić, że z samej etymologii terminu „polityka” wynika, iż dotyczy ona koncepcyjnego wymiaru sterowania w kierunku wyznaczonych celów, a jej immanentną cechą jest całościowe ujęcie celów strategicznych i priorytetów oraz długofalowy charakter. Politykę ostrożnościową w sektorze ubezpieczeń należy rozpatrywać poprzez pryzmat dwóch wzajemnie uzupełniających się filarów makro- i mikroostrożnościowego. Podstawowym, i zarazem najbardziej przejrzystym, kryterium wyodrębnienia podejścia mikro- i makroostrożnościowego w regulacjach nadzorczych, jest sposób percepcji ryzyka stabilności finansowej. W podejściu makroostrożnościowym sektor finansowy traktowany jest jako integralna całość ${ }^{4}$, ze wszystkimi współzależnościami i ich konsekwencjami, co przekłada się na kalibrację narzędzi zarządzania ryzykiem w kierunku uwzględnienia złożonych dynamicznych interakcji sektora finansowego i gospodarki realnej (tabela 1). Natomiast polityka mikroostrożnościowa stanowi celowe oddziaływanie przede wszystkim na zarządzaniem ryzykiem i gospodarką finansową w poszczególnych instytucjach ubezpieczeniowych poprzez zbiór regulacji, narzędzi i metod ich implementacji, mających na celu zapewnienie realizacji zasady realności ochrony ubezpieczeniowej i minimalizację kosztów upadłości

4 A. Crockett, Marrying the micro- and macroprudential dimensions of financial stability, Eleventh International Conference of Banking Supervisors, BIS, Basel 2000; C. Borio, Towards a Macroprudential Framework for Financial Supervision and Regulation?, "BIS Working Papers" 2003, No. 128; M. Brunnermeier, A. Crocket, C. Goodhart, A. Persaud, H. Shin, The fundamental principals of financial regulation, $11^{\text {th }}$ Geneva Report on the World Economy, Geneva 2009. 
zarówno w wymiarze gospodarczym, jak i społecznym. Stąd, generalnie, w literaturze przedmiotu przyjmuje się, że polityka makroostrożnościowa ma na celu zapewnienie stabilności całego sektora finansowego, co w efekcie pozwoli uniknąć kosztów społecznych związanych z zakłóceniami funkcjonowania gospodarki realnej ${ }^{5}$.

Tabela 1. Wymiary polityki ostrożnościowej w sektorze ubezpieczeń

\begin{tabular}{|c|c|c|c|}
\hline Lp. & Kryterium & Makroostrożnościowe & Mikroostrożnościowe \\
\hline 1 & $\begin{array}{l}\text { Cel: } \\
\text { (1) taktyczny } \\
\text { (2) strategiczny }\end{array}$ & $\begin{array}{l}\text { (1) } \text { stabilność systemu finansowego } \\
\text { - ograniczenie zakłóceń funkcjonowania } \\
\text { systemu finansowego w ujęciu } \\
\text { agregatowym } \\
\text { (2) stabilny wzrost gospodarczy - unikanie } \\
\text { kosztów i innych konsekwencji dla } \\
\text { gospodarki, będących efektem zakłóceń } \\
\text { stabilności finansowej w sektorze } \\
\text { ubezpieczeniowym }\end{array}$ & $\begin{array}{l}\text { (1) zapobieganie upadłości instytucji } \\
\text { ubezpieczeniowych - ograniczenie } \\
\text { zakłóceń i dysfunkcji w funkcjonowaniu } \\
\text { poszczególnych instytucji } \\
\text { (2) ochrona interesów beneficjentów usług } \\
\text { ubezpieczeniowych - zagwarantowanie } \\
\text { realizacji zasady realności ochrony } \\
\text { ubezpieczeniowej i redukcja asymetrii } \\
\text { informacyjnej }\end{array}$ \\
\hline 2 & $\begin{array}{l}\text { Kalibracja narzędzi } \\
\text { pomiaru i zarządzania } \\
\text { ryzykiem na: }\end{array}$ & $\begin{array}{l}\text { - współzależność i zbiorowe zachowania } \\
\text { instytucji wobec bodźców zewnętrznych } \\
\text { - rozmiary (tzw. too big to fall) } \\
\text { i powiązania instytucji } \\
\text { ubezpieczeniowych - zwłaszcza } \\
\text { z bankami; potencjalny transfer ryzyka } \\
\text { z innych sektorów } \\
\text { - procykliczność gospodarki, narzędzia } \\
\text { makroekonomiczne - tworzenie buforów } \\
\text { antycyklicznych } \\
\text { - narażenie na ryzyka } \\
\text { pozaubezpieczeniowe - rozdzielenie } \\
\text { klasycznej działalności ubezpieczeniowej } \\
\text { i nieubezpieczeniowej, tj.: udzielanie } \\
\text { pożyczek, emisja instrumentów } \\
\text { finansowych } \\
\text { - ryzyka katastroficzne - testowanie } \\
\text { scenariuszy klęsk w wymiarze } \\
\text { makrogospodarczym, ponadsektorowym }\end{array}$ & $\begin{array}{l}\text { - właściwe zarządzanie ryzykiem } \\
\text { i gospodarką finansową indywidualnych } \\
\text { ubezpieczycieli } \\
\text { - wymogi wypłacalności } \\
\text { - właściwa wycena aktywów i pasywów } \\
\text { - częstotliwość i zakres raportowania } \\
\text { - zarządzanie ryzykiem operacyjnym } \\
\text { - zakres programu reasekuracji } \\
\text { - stopień i zakres wykorzystania dźwigni } \\
\text { finansowej w działalności inwestycyjnej } \\
\text { - zapobieganie realizacji moral hazard } \\
\text { - koncentracja w sektorze } \\
\text { - ograniczenie działalności } \\
\text { pozaubezpieczeniowej }\end{array}$ \\
\hline 3 & Kategoryzacja ryzyka & $\begin{array}{l}\text { endogeniczne - wynikające z: } \\
\text { współzależności instytucji finansowych } \\
\text { i ich zbiorowego zachowania wobec } \\
\text { bodźców zewnętrznych; analiza: danych } \\
\text { zagregowanych i powiązań między } \\
\text { instytucjami }\end{array}$ & $\begin{array}{l}\text { endogeniczne - niezależne od zachowań } \\
\text { indywidualnej instytucji; analiza przede } \\
\text { wszystkim danych indywidualnych oraz } \\
\text { zagregowanych i powiązań w sektorze } \\
\text { (w zależności od potrzeb) }\end{array}$ \\
\hline 4 & $\begin{array}{l}\text { Kalibracja } \\
\text { instrumentów nadzoru }\end{array}$ & $\begin{array}{l}\text { podejście kompleksowe, systemowe, } \\
\text { tzw. top-down - punktem wyjścia jest } \\
\text { ryzyko systemowe }\end{array}$ & $\begin{array}{l}\text { podejście w kategoriach indywidualnej } \\
\text { instytucji ubezpieczeniowej } \\
\text { (tzw. bottom-up) }\end{array}$ \\
\hline
\end{tabular}

5 Zob. A. Crockett A., op.cit.; C. Borio, op.cit.; M. Brunnermeier et al., op.cit.; G. Galati, R. Moessner, Macroprudential policy - a literature review, "BIS Working Papers" 2011, No. 337; S.G. Hanson, A.K. Kashyap, J.C. Stein, IMF 2011; S. Claessens, An Overview of Macroprudential Policy Tools, "IMF Working Paper" 2014, No. WP/14/214; P. Szpunar, Rola polityki makroostrożnościowej w zapobieganiu kryzysom finansowym, "Materiały i Studia" 2012, nr 278, NBP; D. Rosati, Regulacje makroostrożnościowe a stabilność sektora bankowego, "Bank i Kredyt" 2014, 45(4), s. 373-406. 


\begin{tabular}{|c|c|c|c|}
\hline Lp. & Kryterium & Makroostrożnościowe & Mikroostrożnościowe \\
\hline 5 & $\begin{array}{l}\text { Instrumenty } \\
\text { zarządzania ryzykiem }\end{array}$ & $\begin{array}{l}\text { skierowane na redukcje ryzyka } \\
\text { w wymiarze: } \\
\text { - czasowym, tj. np. bufory antycykliczne } \\
\text { - strukturalnym }\end{array}$ & $\begin{array}{l}\text { skierowane na redukcję ryzyka } \\
\text { głównie w wymiarze czasowym, } \\
\text { częściowo w wymiarze strukturalnym, } \\
\text { np. ograniczenie powiązań między } \\
\text { instytucjami }\end{array}$ \\
\hline 6 & Podstawowe korzyści & $\begin{array}{l}\text { - wspieranie stabilnego wzrostu } \\
\text { gospodarczego } \\
\text { - zapewnienie stabilności finansowej } \\
\text { sektora finansowego } \\
\text { - osiaganie celów społecznych } \\
\text { i politycznych (np. gromadzenie } \\
\text { oszczędności na cele emerytalne) }\end{array}$ & $\begin{array}{l}\text { - ochrona beneficjentów instytucji } \\
\text { ubezpieczeniowych } \\
\text { - redukcja prawdopodobieństwa upadłości } \\
\text { instytucji ubezpieczeniowych } \\
\text { - redukcja abuzywnych praktyk rynkowych } \\
\text { w sektorze ubezpieczeń } \\
\text { - redukcja asymetrii informacji i wzrost } \\
\text { transparentności sektora zarówno dla } \\
\text { nadzoru, beneficjentów, jak i dla i opinii } \\
\text { publicznej }\end{array}$ \\
\hline 7 & Zasadnicze koszty & \multicolumn{2}{|c|}{$\begin{array}{l}\text { (1) koszty publiczne: } \\
\text { - koszty nadzoru } \\
\text { - koszty procedur legislacyjnych } \\
\text { (2) koszty ponoszone przez instytucje ubezpieczeniowe: } \\
\text { - koszty administracyjne, rozbudowy infrastruktury, np. IT } \\
\text { - koszty usług zewnętrznych, outsourcingu, np. koszty konsultingu, audytu } \\
\text { - koszty utraconych możliwości, np. koszty zakazu prowadzenia (lub znacznego } \\
\text { ograniczenia) działalności pozaubezpieczeniowej lub nietradycyjnie ubezpieczeniowej } \\
\text { - koszty zmian strukturalnych w sektorze wskutek wdrażania regulacji nadzorczych, } \\
\text { - koszty zwiazzane ze zmianami na rynku wskutek wprowadzenia regulacji, np. spadek } \\
\text { popytu na niektóre produkty } \\
\text { - koszty związane z podwyższaniem wymogów kapitałowych, wymogów raportowania } \\
\text { etc. }\end{array}$} \\
\hline
\end{tabular}

Źródło: Opracowanie własne na podstawie C. Borio, Towards a Macroprudential Framework for Financial Supervision and Regulation?, "BIS Working Papers" 2003, No. 128; Macroprudential Policy and Surveillance in Insurance, IAIS, 18 July 2013; M. Eling, D. Pankoke, Costs and Benefits of Insurance Regulation - An Empirical Assessment from the Industry Perspective, Institute of Insurance Economics, University of St. Gallen, $15^{\text {th }}$ July 2014.

W podejściu mikroostrożnościowym, w klasycznej postaci, zakłada się, iż gwarancją stabilności sektora jest zapewnienie właściwego funkcjonowania poszczególnych instytucji ubezpieczeniowych, zgodnie z zasadą, że dobra kondycja indywidualnych ubezpieczycieli jest warunkiem koniecznym i wystarczającym do tworzenia solidnego stabilnego sektora ubezpieczeń w wymiarze makrogospodarczym ${ }^{6}$. Niemniej jednak, kluczową rolę w kontekście kreowania regulacji zarówno mikro-, jak i makroostrożnościowych, odgrywają stabilność sektora ubezpieczeń oraz zarządzanie ryzykiem. Obydwa poziomy regulacji mają przede wszystkim charakter prewencyjny, czyli skupiają się na wypracowywaniu mechanizmów wczesnego ostrzegania i rekomendacjach zapobiegających realizacji ryzyka ${ }^{7}$. Podejście mikroostrożnościowe

6 Zob. Macroprudential Policy and Surveillance in Insurance, IAIS, 18 July 2013.

7 Zob. P. Szpunar, op.cit.; M. Olszak, Polityka ostrożnościowa w ujęciu makro - cel, instrumenty i architektura instytucjonalna, „Problemy Zarządzania” 2012, nr 4(39), t. 1, s. 7-32; D. Rosati, op.cit., s. 373-406. 
jest realizowane na poziomie krajowych organów nadzorczych, natomiast podejście makroostrożnościowe jest domeną instytucji nadzorczych ponadnarodowych, tj.: ESRB, IAIS, EIOPA. Niemniej jednak, mogą wystąpić też konflikty interesów i kompetencji w zakresie podejścia mikro- i makroostrożnościowego, zwłaszcza w okresach dekoniunktury ${ }^{8}$. Przeciwnicy podejścia mikroostrożnościowego argumentują, że regulacje mikroostrożnościowe kreują wysoce homogeniczne zachowania podmiotów rynkowych i tym samym przyczyniają się do podwyższania ryzyka systemowego'. Natomiast zwolennicy podejścia mikroostrożnościowego uważają, że właściwie funkcjonujący nadzór mikroostrożnościowy w zasadzie wystarczy do prewencji ryzyka systemowego, zaś sterowanie z poziomu makro kreuje dodatkowe rodzaje ryzyka ${ }^{10}$.

\section{Instrumenty polityki makroostrożnościowej w sektorze ubezpieczeń}

Obecnie w sektorze ubezpieczeń podejście makro- i mikrostrożnościowe rozpatrywane są jako dwa komplementarne poziomy regulacji nadzorczych ${ }^{11}$, prowadzące w istocie do zasadniczego efektu - zapewnienia stabilności finansowej, koniecznej nie tylko do realizacji funkcji ochrony ubezpieczeniowej, ale - w szerszym wymiarze - do stabilnego rozwoju gospodarczego. Biorąc pod uwagę zasadę komplementarności regulacji nadzorczych, klasyczne instrumenty polityki mikroostrożnościowej sektora ubezpieczeniowego często są wkomponowane w zbiór narzędzi wykorzystywanych przez nadzór makroostrożnościowy - jako tzw. instrumenty pierwszego szczebla nadzoru (first-layer instruments) $)^{12}$, pozwalające na identyfikację sygnałów

8 S.G. Hanson, A.K. Kashyap, J.C. Stein, op.cit.; P. Angelini, S. Nicoletti-Altimari, I. Visco, Macroprudential, Microprudential and Monetary Policies: Conflicts, Complementarities and Trade-Offs, "Occasional Papers" 2012, No. 140, Bank of Italy; J. Osiński, K. Seal, L. Hoogduin, Macroprudential and Microprudential Policies: Towards Cohabitation, "IMF Staff Discussion" 2013, Note SDN/13/05; D. Schoenmaker, J. Kremers, Financial stability and proper business conduct: Can supervisory structure help to achieve these objectives?, w: Institutional Structure of Financial Regulation: Theories and International Experiences, red. R. Huang, D. Schoenmaker, Routledge, London 2014, s. 29-39.

9 A. Persaud, Macro-Prudential and Micro-Prudential Regulation, The University of Warwick 2009; Ch. Zhou, Why the micro-prudential regulation fails? The impact on systemic risk by imposing a capital requirement, "DNB Working Paper" 2010, No. 256.

10 Zob. A. Aiyar, Ch.W. Calomiris, T. Wielądek 2012.

11 Zob. Macroprudential..., op.cit.; Allocating macro-prudential powers, Reports of the Advisory Scientific Committee 2014, No. 5, ESRB; J. Osiński, K. Seal, L. Hoogduin, op.cit.

12 Zob. G. Galati, R. Moessner, Macroprudential policy - a literature review, "BIS Working Papers" 2011, No. 337; B. Schmitz, Macroprudential financial market regulation: Aims, implementation, and implications for developing and emerging economies, "Discussion Paper Deutsches Institut für Entwicklungspolitik" 2013, No. 20, Bonn. 
narastania ryzyka w systemie poprzez monitorowanie właściwego stabilnego funkcjonowania sektora ubezpieczeń ${ }^{13}$. Drugi zaś szczebel instrumentarium nadzorczego (second-layer instruments) stanowią instrumenty specjalnie dedykowane do ograniczania ryzyka systemowego. Jest to raczej pewne kontinuum działań i regulacji nadzorczych, zakładające symultaniczne (od szczegółu do ogółu) oraz syntetyzujące (od ogółu do szczegółu) wykorzystanie podejścia analitycznego.

Należy zdawać sobie sprawę z obiektywnych trudności w precyzyjnym rozgraniczeniu instrumentarium mikro- i makroostrożnościowego zarówno w publikacjach, jak i w praktyce nadzorczej. Trudności te wynikają z co najmniej dwóch kwestii. Po pierwsze, podejście mikroostrożnościowe, historycznie znacznie starsze i w zasadzie dominujące jak dotychczas, skupiało się co prawda przede wszystkim na kwestiach zapobiegania niewypłacalności instytucji ubezpieczeniowych oraz zapewnieniu realności ochrony ubezpieczeniowej, lecz obejmowało też, przynajmniej w części, kwestie związane z funkcjonowaniem tego sektora w skali makro, traktując sektor ubezpieczeń jako element systemu stanowiącego integralną całość, zapewniającego prawidłowe funkcjonowanie gospodarki. Po drugie, w podejściu mikroostrożnościowym operuje się bardzo szerokim instrumentarium. Można tu wyodrębnić instrumenty o charakterze i zasięgu wyraźnie w skali mikro-, skierowane na oddziaływanie przede wszystkim w obszarze np. płynności, ale też narzędzia pozwalające na oddziaływanie na strukturę sektora, powiązania kapitałowe pomiędzy poszczególnymi podmiotami oraz skalę ich zaangażowania kapitałowego na rynku instrumentów finansowych, a także na sferę realną gospodarki (np. limity ilościowe). Stąd, w podejściu makroostrożnościowym szeroko wykorzystywane są klasyczne instrumenty mikroostrożnościowe, które są modyfikowane i adaptowane poprzez skalowanie ryzyka systemowego w makro-skali ${ }^{14}$, np. bufory antycykliczne stanowią część rozwiązań w ramach wymogów kapitałowych zdefiniowanych w Dyrektywie Solvency II. Ponadto, mamy do czynienia z łączeniem instrumentów makro- i mikroostrożnościowych w jednej regulacji prawnej, np. ochrona interesów beneficjentów stanowi element polityki makroostrożnościowej przy wyodrębnieniu systemowo ważnych instytucji ubezpieczeniowych (Global Systemically Important Insurers - GSII). Takie podejście uzasadnione jest faktem, że przynajmniej część instrumentów mikroostrożnościowych przyczynia się również do redukcji ryzyka w makroskali, np. stosowanie ograniczeń w zakresie prowadzenia działalności pozaubezpieczeniowej, limitowanie angażowania się na rynku kapitałowym, ograniczenia dotyczące derywatów.

${ }_{13}$ Macroprudential..., op.cit.

${ }^{14}$ Zob. G. Galati, R. Moessner, op.cit.; Bank of England 2011; S. Claessens, An Overview of Macroprudential Policy Tools, "IMF Working Paper" 2014, No. WP/14/214; M. Olszak, op.cit., s. 7-32. 
Tabela 2. Instrumenty polityki makroostrożnościowej w sektorze ubezpieczeń - klasyfikacja z punktu widzenia kryterium celu

\begin{tabular}{|c|c|c|c|}
\hline & $\begin{array}{c}\text { Obszary } \\
\text { oddziaływania }\end{array}$ & Cel stosowania & Wybrane instrumenty \\
\hline \multirow[b]{2}{*}{ 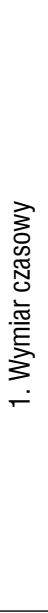 } & \multirow[t]{2}{*}{ procykliczność } & $\begin{array}{l}\text { 1) ograniczenie } \\
\text { wykorzystania dźwigni } \\
\text { finansowej }\end{array}$ & $\begin{array}{l}\text { - korekty dopasowujące i bufory antycykliczne } \\
\text { - wzrost wymogów kapitałowych } \\
\text { - zalecenia w zakresie podziału zysków } \\
\text { - wagi ryzyka w portfelu lokat } \\
\text { - ograniczenia zakresu działalności (np. wykorzystywanie } \\
\text { derywatów, działalności nieubezpieczeniowej, typowo } \\
\text { spekulacyjnej, inwestycyjnej) }\end{array}$ \\
\hline & & $\begin{array}{l}\text { 2) redukcja niedopasowania } \\
\text { czasu trwania aktywów } \\
\text { i pasywów (maturity gap) } \\
\text { oraz wzrost płynności }\end{array}$ & $\begin{array}{l}\text { - } \text { symetryczny mechanizm dostosowania (np. w szacowaniu } \\
\text { ryzyka rynkowego) } \\
\text { - limity kwot dopuszczonych środków własnych na pokrycie } \\
\text { minimalnego wymogu kapitałowego (MCR) oraz kapitałowego } \\
\text { wymogu wypłacalności (SCR) } \\
\text { - narzuty kapitałowe } \\
\text { - wymogi asset liability management (ALM), } \\
\text { - zastosowanie korekty dopasowującej w liczeniu } \\
\text { najlepszego oszacowania zobowiązań ubezpieczeniowych } \\
\text { i reasekuracyjnych (np. wpływ zmian spreadów aktywów } \\
\text { na korektę dopasowującą, a zatem na wartość rezerw } \\
\text { techniczno-ubezpieczeniowych) }\end{array}$ \\
\hline \multirow{3}{*}{ 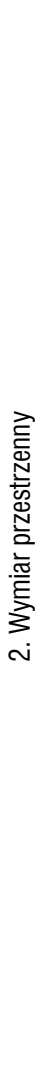 } & \multirow[t]{3}{*}{$\begin{array}{l}\text { 1) wymiar } \\
\text { strukturalny } \\
\text { międzysektorowy }\end{array}$} & $\begin{array}{l}\text { 1) zarażanie: } \\
\text { a) wzajemne powiązania } \\
\text { b) łączna ekspozycja }\end{array}$ & $\begin{array}{l}\text { - zasady nadzoru nad grupami kapitałowymi } \\
\text { - nadzór nad zaangażowaniem w tworzenie podmiotów } \\
\text { zależnych } \\
\text { - limity koncentracji - ograniczenie powiązań aktywów } \\
\text { w ramach sektora finansowego (udzielania pożyczek, } \\
\text { instrumenty wyemitowane przez instytucje finansowe } \\
\text { w portfelu aktywów ubezpieczyciela (papiery dłużne, } \\
\text { certyfikaty depozytowe, akcje) } \\
\text { - } \text { kontrola powiązań pasywów w ramach sektora finansowego: } \\
\text { suma otrzymanych pożyczek od instytucji finansowych, } \\
\text { emisje papierów wartościowych skierowane do instytucji } \\
\text { finansowych (instrumenty dłużne, certyfikaty) } \\
\text { - miary ryzyka koncentracji: ekspozycja aktywów } \\
\text { na największych kontrahentów, zakres reasekuracji } \\
\text { - ekspozycja na ryzyko kredytowe emitenta portfela inwestycji } \\
\text { - ocena struktury obrotów: ekspozycja na ryzyko rynkowe } \\
\text { - macierze korelacji ryzyk, wagi ryzyka, limity ekspozycji }\end{array}$ \\
\hline & & $\begin{array}{l}\text { 2) bańki spekulacyjne } \\
\text { i nagła wymuszona } \\
\text { wyprzedaż aktywów }\end{array}$ & $\begin{array}{l}\text { - } \text { metodologia VaR do szacowania MCR i SCR } \\
\text { - symetryczny mechanizm dostosowania (np. w szacowaniu } \\
\text { ryzyka rynkowego) } \\
\text { - wycena pozycji aktywów wg wartości rynkowej } \\
\text { - } \text { miary ryzyka płynności w ekspozycji na potencjalne szoki } \\
\text { rynkowe } \\
\text { - wycena wartości zobowiązań wg najlepszego oszacowania } \\
\text { - wymogi kapitałowe w ujęciu nominalnym oraz adekwatność } \\
\text { na podstawie podejmowanego ryzyka }\end{array}$ \\
\hline & & 3) GSII & $\begin{array}{l}\text { - utworzenie planów zarządzania kryzysowego } \\
\text { - opracowanie planów naprawczych } \\
\text { - } \text { bufor kapitałowy ryzyka systemowego - podwyższenie } \\
\text { wymogów kapitałowych, zwiększenie zdolności do absorbcji } \\
\text { potencjalnych strat (Higher Loss Absorption) } \\
\text { - limity i restrykcje dotyczące zaangażowania instytucji } \\
\text { ubezpieczeniowych w działalność nie stricte ubezpieczeniową, } \\
\text { tj. zakaz emisji CDS, }\end{array}$ \\
\hline
\end{tabular}




\begin{tabular}{|c|c|c|c|}
\hline & $\begin{array}{c}\text { Obszary } \\
\text { oddziaływania }\end{array}$ & Cel stosowania & Wybrane instrumenty \\
\hline \multirow{3}{*}{ 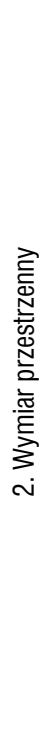 } & & & $\begin{array}{l}\text { - podwyższone wymogi kapitałowe dla działalności } \\
\text { nietradycyjnej i pozaubezpieczeniowej } \\
\text { - wymogi dla dokonywania transakcji wewnątrz grupy } \\
\text { kapitałowej oraz transferu ryzyka }\end{array}$ \\
\hline & & $\begin{array}{l}\text { 4) wrażliwość strukturalna } \\
\text { sektora - redukcja poprzez } \\
\text { wprowadzanie standardów } \\
\text { zachowań rynkowych oraz } \\
\text { infrastruktury sektora }\end{array}$ & $\begin{array}{l}\text { zmniejszenie asymetrii informacyinej poprzez: } \\
\text { - wymogi dotyczące podawania informacji do wiadomości } \\
\text { publicznej (Dyrektywa Solvency II i akty wykonawcze), } \\
\text { - Rekomendacja U dotycząca dobrych praktyk w zakresie } \\
\text { bancassurance, KNF, } \\
\text { - standaryzacja produktów - wymogi informacyjne dla } \\
\text { - ubezpieczeń z elementem inwestycyjnym (KIDs, IMD2) } \\
\text { - wytyczne dla zakładów ubezpieczeń dotyczące dystrybucji } \\
\text { ubezpieczeń, KNF } 2014\end{array}$ \\
\hline & $\begin{array}{l}\text { 2) wymiar } \\
\text { przestrzenny } \\
\text { globalny }\end{array}$ & $\begin{array}{l}\text { 1) arbitraż regulacyjny } \\
\text { 2) migracja kapitału } \\
\text { i ryzyka }\end{array}$ & $\begin{array}{l}\text { - przyjęcie transgranicznych porozumień o wspótpracy między } \\
\text { instytucjami } \\
\text { - ponadnarodowe wdrażanie zaleceń dla ważnych systemowo } \\
\text { instytucji (Key Attributes of Effective Resolution Regimes for } \\
\text { Financial Institutions, FSB, October 2011) } \\
\text { - standardy działalności (Insurance Capital Standard (ICS) } \\
\text { Principles, IAIS, } 12 \text { September 2014) } \\
\text { - ponadnarodowe wymogi kapitałowe dla GSII (Basic Capital } \\
\text { Requirements for Global Systemically Important Insurers, IAIS } \\
\text { 23 October 2014) }\end{array}$ \\
\hline
\end{tabular}

Źródło: Opracowanie własne na podstawie B. Schmitz, Macroprudential financial market regulation: Aims, implementation, and implications for developing and emerging economies, "Discussion Paper Deutsches Institut für Entwicklungspolitik" 2013, No. 20, Bonn.

Zadania polityki makroostrożnościowej traktowane są jako wypełnienie pewnej luki między obszarami polityki makrogospodraczej, tj. np. polityką pieniężną a polityką mikroostrożnościową ${ }^{15}$, precyzują zakres nadzoru makroostrożnościwego jako uzupełniający w relacji do mikroostrożnościowego. Do zakresu analiz organów mikroostrożnościowych należą bowiem: (1) kompleksowa identyfikacja i monitorowanie ryzyka w sektorze ubezpieczeń na różnych poziomach funkcjonowania i jego interakcji z gospodarką realną oraz gromadzenie i przetwarzanie danych instytucji ubezpieczeniowych w ujęciu indywidualnym, jak i zagregowanym; (2) identyfikacja źródeł szoków zarówno w skali makroekonomicznej, jak i indywidualnej ekspozycji instytucji ubezpieczeniowych, monitorowanie i ograniczanie koncentracji sektora, a także współzależności kapitałowych, w celu ograniczania narastania ryzyka sektora, a w efekcie i ryzyka systemowego. Natomiast nadzór makroostrożnościowy powinien koncentrować się przede wszystkim na: (1) monitorowaniu i szacowaniu ryzyka stabilności systemu finansowego jako całości; (2) wypracowaniu narzędzi mających na celu prewencję

${ }_{15}$ Macroprudential policy: an organizing framework, International Monetary Fund, Washington 2011; D. Schoenmaker, An Integrated Financial Framework for the Banking Union: Don't Forget Macro-Prudential Supervision, "Economic Papers" 2013, No. 495; D. Rosati, op.cit., s. 373-406; Macroprudential Policy and Surveillance in Insurance, IAIS, op.cit. 
i ograniczenie dotkliwości - w wymiarze przestrzennym i czasowym - negatywnych efektów zakłóceń funkcjonowania sektora ubezpieczeniowego oraz rozprzestrzeniania tych efektów na inne sektory systemu finansowego i sferę gospodarki realnej.

W podejściu makroostrożnościowym przedmiotem zainteresowania są współzależności między instytucjami wchodzącymi w skład całego sektora finansowego, stąd narzędzia nadzorcze koncentrują się przede wszystkim na: zachowaniach zbiorowych instytucji, powiązaniach kapitałowych, koncentracji sektora, zjawiskach procyklicznych ${ }^{16}$. Instrumenty polityki makroostrożnościowej w sektorze ubezpieczeń można rozpatrywać $\mathrm{w}$ wymiarze czasowym i przestrzennym (tabela 2).

Mając na uwadze, że ryzyko stabilności systemu finansowego jest generowane przede wszystkim przez działalność nietradycyjną lub pozaubezpieczeniową instytucji ubezpieczeniowej ${ }^{17}$ - bowiem tutaj pojawiają się silne powiązania $\mathrm{z}$ innymi instytucjami finansowymi oraz ekspozycja na ryzyka nieubezpieczeniowe, właściwe dla rynków finansowych - znaczna część instrumentów polityki makroostrożnościowej skierowana jest na ograniczenie wykorzystania dźwigni finansowej oraz redukcję niedopasowania czasu trwania portfela aktywów i portfela zobowiązań. Znaczna część instrumentów polityki makroostrożnościowej jest skierowana na ograniczenie skutków procykliczności dla kondycji finansowej sektora ubezpieczeń. Wprowadza się korekty antycykliczne, zwłaszcza przy szacowaniu kapitału na pokrycie ryzyka instytucji ubezpieczeniowych. Do instrumentów mających na celu redukcję niedopasowania czasu trwania portfela aktywów i portfela zobowiązań zalicza się głównie: wymogi ALM, limity klasyfikacji środków własnych, korekty dopasowujące. Wysoką rangę przypisuje się obecnie wypracowaniu instrumentów makroostrożnościowych $\mathrm{w}$ wymiarze przestrzennym.

\section{Instrumenty polityki mikroostrożnościowej w sektorze ubezpieczeń}

W podejściu mikroostrożnościowym przedmiotem analiz są parametry indywidualne poszczególnych instytucji ubezpieczeniowych, stąd kalibracja narzędzi

\footnotetext{
${ }^{16}$ Macroprudential policy: an organizing framework, op.cit.

17 Systemic Risk in Insurance, An Analysis of insurance and financial stability, The Geneva Association, Geneva, March 2010; Insurance and Financial Stability, IAIS, November 2011; T. Czerwińska, Ryzyko systemowe w sektorze ubezpieczeń - analiza ekspozycji w krajach Unii Europejskiej, "Problemy Zarządzania" 2014, nr 4; Ch. Thimann, How Insurers Differ from Banks: A Primer on Systemic Regulation, Systemic Risk Centre, The London School of Economics and Political Science, "SRC Special Paper" 2014, No. 3.
} 
i regulacji nadzorczych obejmuje zwłaszcza: wypłacalność, płynność, zakres reasekuracji, wycenę portfela aktywów, tworzenie i rozwiązywanie rezerw techniczno-ubezpieczeniowych, kalkulacje składki. Instrumenty nadzoru mikroostrożnościowego mogą być formułowane w różnej formie, co wiąże się ze skutecznością ich oddziaływania, w postaci:

1) regulacji prawnych - największy stopień skuteczności oddziaływania (pod warunkiem właściwej kalibracji narzędzi), najczęściej są to tzw. pakiety regulacyjne, tj. np. Solvency II wraz z aktami wykonawczymi, które są implementowane przez poszczególne państwa UE $\mathrm{w}$ formie regulacji krajowych,

2) różnego typu: zaleceń, rekomendacji, kodeksów dobrych praktyk czy też wydawanych opinii ${ }^{18}$ - są to tzw. miękkie formy oddziaływania polityki mikroostrożnościowej; z reguły prezentują one stanowisko organu nadzoru w określonej kwestii, tj. np.: Rekomendacji KNF dla zakładów ubezpieczeń i reasekuracji w sprawie polityki wypłaty dywidend; Wytyczne KNF dla zakładów ubezpieczeń dotyczace dystrybucji ubezpieczeńn ${ }^{19}$ i mają charakter pewnych pouczeń, czasem doraźnych, co do zastosowania określonych rozwiązań w danych warunkach rynkowych, skierowanych do konkretnego zakładu lub do ogółu podmiotów w sektorze, które często wprowadzane są na zasadzie comply or explain.

Mając na uwadze pewne ograniczenia w stosowaniu oraz koszty i korzyści poszczególnych rozwiązań ${ }^{20}$, wydaje się, że instrumentarium ostrożnościowe w sektorze ubezpieczeń powinno stanowić pewną kompilację nakazowych elementów oddziaływania, w formie tzw. „twardych” regulacji, oraz w formie regulacji „miękkich”, czyli rekomendacji i zaleceń. Przy tym warto zauważyć, że koncepcja nadzoru ewoluuje obecnie raczej w kierunku większej elastyczności regulacji, co umożliwia bieżący dialog organu nadzoru $\mathrm{z}$ nadzorowanymi podmiotami. Wskazuje na to:

1) poszerzenie zakresu możliwości wydawania indywidualnych wytycznych zakładom ubezpieczeń - w świetle obowiązujących regulacji organ nadzoru ma uprawnienia do wydawania takich indywidualnych wytycznych głównie w celu zapewnienia: a) zgodności prowadzonej działalności z prawem, b) permanentnej zdolności do wywiązywania się z podjętych z tytułu zawartych umów zobowiązań, co ma na względzie przede wszystkim ochronę interesów beneficjentów usług ubezpieczeniowych ${ }^{21}$. Przewiduje się dodatkowo poszerzenie zakresu tych

18 Zob. A. Dobrzańska, Polityka makroostrożnościowa - zagadnienia instytucjonalne. Teoria i dotychczasowe doświadczenia w Unii Europejskiej, „Materiały i Studia” 2014, nr 307, NBP.

19 KNF 2014.

${ }_{20}$ Zob. M. Marcinkowska, Regulation and self-regulation in banking: in search of optimum, "Bank i Kredyt" 2013, No. 2, s. 119-158.

${ }^{21}$ Ustawa z dnia 22 maja 2003 roku o działalności ubezpieczeniowej, art. 209. 
wytycznych o zalecenia dotyczące poprawy i wzmocnienia systemu zarządzania oraz ograniczenia ryzyka w działalności zakładu ubezpieczeń lub reasekuracji ${ }^{22}$,

2) nadanie prawa do wydawania wytycznych adresowanych „do rynku” - dedykowanych dla ogółu zakładów zarówno w zakresie realizacji zaleceń EIOPA jako nadzoru makroostrożnościowego, jak i na podstawie generalizacji wniosków z zidentyfikowanych praktyk indywidualnych podmiotów, np. w zakresie ograniczenia ryzyka lub zapewnienia trwałej zdolności zakładów do wykonywania zobowiązań, co pozwala na realizację funkcji prewencyjnej nadzoru i umożliwia kształtowanie pewnych praktyk w sektorze ubezpieczeniowym; wytyczne takie, co prawda, nie są wiążące dla zakładów, bowiem jak wskazuje orzecznictwo ${ }^{23}$ organ nadzoru nie może ograniczać prawa do wolności gospodarczej oraz nakładać na zakłady dodatkowych, niewynikających z przepisów prawa obowiązków ${ }^{24}$; niemniej jednak, w wypadku niezastosowania się do tych zaleceń, organ nadzoru podaje tę informację do publicznej wiadomości, co spełnia funkcję redukcji asymetrii informacyjnej,

3) ustanowienie instytucji bieżącego dialogu między organem nadzoru a nadzorowanymi podmiotami - o ile w wypadku wytycznych kierowanych do indywidualnych podmiotów organ nadzoru ma możliwość nadania im mocy decyzji i rygoru natychmiastowej wykonalności, jeśli uzasadnia to interes beneficjentów umów ubezpieczenia, to w wypadku zaleceń kierowanych do ogółu zakładów, organ nadzoru będzie zobowiązany do przeprowadzania konsultacji projektu wytycznych z zainteresowanymi podmiotami oraz dokonywania oceny przewidywanych skutków ich wdrożenia w aspekcie zarówno gospodarczym, jak i społecznym, natomiast zakłady mają prawo do wypracowania własnego podejścia w kwestii realizacji wytyczonych przez nadzór celów i odmowy wdrożenia zaleceń w sensie implementacji konkretnych sposobów rozwiązania problemów ${ }^{25}$.

22 Projekt założeń do projektu Ustawy o działalności ubezpieczeniowej i reasekuracyjnej (wersja z 12 grudnia 2014) (RM-10-109-14), pkt. 14.2.

${ }^{23}$ Wyrok Trybunału Konstytucyjnego z 28 czerwca 2000 r. (sygn. K 25/99 (OTK 2000/51141)) w sprawie rekomendacji Zarządu NBP, Rady Polityki Pieniężnej oraz Sądu Najwyższego (z dnia 7 grudnia 1999 r., sygn. I CKN 796/99 (LEX m 38875)) w odniesieniu do rekomendacji Komisji Nadzoru Bankowego, gdzie wskazano, że wydawanych zarządzeń prezesa NBP oraz uchwał Komisji Nadzoru Bankowego nie można zaliczać do prawa powszechnie obowiązującego.

24 Zob. Projekt założeń do projektu Ustawy o działalności ubezpieczeniowej i reasekuracyjnej (wersja z 12 grudnia 2014) (RM-10-109-14), pkt. 14.1.

${ }_{25}$ Projekt założeń do projektu Ustawy o działalności ubezpieczeniowej i reasekuracyjnej (wersja z 12 grudnia 2014) (RM-10-109-14), pkt. 14.2. 
W zasadzie optymalne regulacje mikroostrożnościowe powinny prowadzić $\mathrm{do}^{26}$ : (1) minimalizacji kosztów niewypłacalności instytucji ubezpieczeniowych, (2) właściwej wyceny ryzyka i kalkulacji ceny ubezpieczenia, (3) właściwych praktyk rynkowych, (4) wypracowywania własnych wewnętrznych narzędzi nadzorczych i mechanizmów kontrolnych do monitorowania praktyk instytucji oraz współpracujących z nią pośredników ubezpieczeniowych, a także (5) zapewniać adekwatną podaż usług ubezpieczeniowych. Do warunków skuteczności regulacji mikroostrożnościowych należy zaliczyć27: niezależność i odpowiedzialność organu nadzoru, wykorzystywanie instrumentów dyscypliny rynkowej, restrykcje w zakresie udzielania pomocy publicznej oraz wypracowanie rozwiązań umożliwiających minimalizację kosztów upadłości instytucji ubezpieczeniowych. Mając na uwadze wymienione cele, można wyodrębnić instrumenty nadzoru mikroosrożnościowego w sektorze ubezpieczeniowym w następujących zasadniczych obszarach ${ }^{28}$ :

1) standardy wykonywania działalności - standardy ładu korporacyjnego, wymogi w zakresie wprowadzenia skutecznego systemu zarządzania, który zapewni prawidłowe i ostrożne zarządzanie prowadzoną działalnością. System ten powinien obejmować: odpowiednią, przejrzystą strukturę organizacyjną, jasno przypisane zakresy odpowiedzialności oraz skuteczny system raportowania informacji. Wyodrębnia się funkcje: aktuarialną, zarządzania instytucją ubezpieczeniową w zgodności z przepisami, system zarządzania ryzykiem i kontroli wewnętrznej, a także wymogi dotyczące kompetencji i reputacji osób, które zarządzają zakładem lub pełnią tzw. kluczowe funkcje ${ }^{29}$,

2) płynność i wypłacalność - instrumenty w tym obszarze mają na celu redukcję moral hazard poprzez ustanowienie standardów adekwatności kapitałowej w relacji do skali ryzyka podejmowanego przez instytucję ubezpieczeniową; instrumenty polityki mikroostrożnościowej są skierowane przede wszystkim - w ujęciu statycznym - na oddziaływanie na strukturę majątkowo-kapitałową instytucji ubezpieczeniowej (tzw. instrumenty bilansowe) oraz - w ujęciu dynamicznym - na kształtowanie przepływów środków pieniężnych w obszarze działalności

${ }^{26}$ Za: R.W. Klein, Principles for Insurance Regulation: An Evaluation of Current Practices and Potential Reforms, January 312011.

27 Zob. M. Dewatripont, J. Tirole, The Prudential Regulation of Banks,, MIT Press, Cambridge 1994.

${ }_{28} \mathrm{Za}$ : Competition and related regulation issues in the insurance industry, OECD 1998; E.N. White, Lessons From The History Of Bank Examination And Supervision in the United States, 1863-2008, w: Financial Market Regulation in the Wake of Financial Crises: The Historical Experience, red. A. Gigliobianco, G. Toniolo, "Banca d'Italia" 2009, No. 1; C. Giordano Prudential Regulation and Supervision Instruments and Aims: A General Framework, w: Ibidem, s. 243-251; R.W. Klein, op.cit.

${ }^{29}$ Dyrektywa Parlamentu Europejskiego i Rady 2009/138/WE z 25 listopada 2009 r. w sprawie podejmowania i prowadzenia działalności ubezpieczeniowej i reasekuracyjnej (Wypłacalność II) Dz. U. UE z 17/12/2009, art. 41-50. 
technicznej oraz inwestycyjnej; wprowadzane są m.in. kategoryzacja jakości środków własnych na pokrycie podjętych zobowiązań, wymogi asset liability management (ALM), zasady szacowania SCR i MCR, zasady alokacji portfela lokat, obliczenie najlepszego oszacowania,

3) warunki konkurencji w sektorze - ograniczenia konkurencji poprzez tworzenie barier wejścia - wyjścia, licencjonowanie podmiotów, limity ekonomii skali, tj. ograniczenia w zakresie fuzji, przejęć horyzontalnych, limity zakresu i dywersyfikacji działalności, tj.: zasada branżowości, ograniczenie możliwości prowadzenia działalności pozaubezpieczeniowej, warunki outsourcingu czynności,

4) praktyki rynkowe - celem jest przede wszystkim ochrona interesów beneficjentów i wzmocnienie ich pozycji na rynku usług ubezpieczeniowych; wprowadzane są: zasady dystrybucji usług ubezpieczeniowych, standardy dobrych praktyk, monitorowanie klauzul abuzywnych, wymogi w zakresie polityki informacyjnej w relacji $\mathrm{z}$ beneficjentami, zwłaszcza polis $\mathrm{z}$ ubezpieczeniowym funduszem kapitałowym,

5) monitorowanie i raportowanie - celem jest zapewnienie transparentności sektora oraz efektywny nadzór nad działalnością instytucji ubezpieczeniowych.

Wyodrębnione obszary zazębiają się wzajemnie, tworząc całość, bowiem zabezpieczenie wypłacalności instytucji ubezpieczeniowej oraz jej transparentności i właściwego zarządzania na poziomie operacyjnym, a także strategicznym jest gwarancją realizacji realności ochrony ubezpieczeniowej. Na poziomie mikroostrożnościowym organy nadzorcze koncentrują się przede wszystkim na prewencji niewypłacalności instytucji ubezpieczeniowej oraz prowadzeniu przez nią właściwych praktyk rynkowych, zarówno w zakresie zarzadząnia samą instytucją ubezpieczeniową, jak i szerzej - w kontekście funkcjonowania na rynku pośrednictwa finansowego praktyk.

\section{Podsumowanie}

Istotne zmiany w zakresie infrastruktury instytucjonalno-nadzorczej oraz regulacyjnej w sektorze ubezpieczeń (i nie tylko) powodują, że analiza i systematyka wypracowywanych narzędzi nastręcza pewnych trudności. Prowadzone równolegle w ramach IAIS, EIOPA oraz ERSB i FSB prace nad nowymi rozwiązaniami w zakresie instrumentarium zarówno mikro- jak i makroostrożnościwego powodują, że dynamika zmian jest duża, zaś brakuje pewnej transparentności i jednolitości. Stąd powstaje obawa o spójność ostatecznego kształtu regulacji i instrumentarium nadzorczego nie tylko w samym sektorze ubezpieczeń, ale w szerszym kontekście. W przeciwnym wypadku wygenerują one dodatkowe ryzyko - ryzyko regulacyjne. 
Obecnie polityka ostrożnościowa w sektorze ubezpieczeniowym koncentruje się na ograniczeniu asymetrii informacji oraz negatywnej selekcji, a także ograniczaniu powstawania i narastania ryzyka systemowego. Analiza instrumentarium w podejściu mikro- i makroostrożnościowym wykazuje, że w znacznej części mają one wspólną genezę, różnią się zaś kalibracją, w wypadku instrumentów makroostrożnościowych - redukcja ryzyka systemowego, zaś mikroostrożnościowych - zapewnienie płynności i wypłacalności. Projektowane w sektorze ubezpieczeń instrumentarium makroostrożnościowe w znacznej mierze czerpie z wzorców sektora bankowego, znacznie bardziej zaawansowanego w tym zakresie. Podobnie jak w sektorze bankowym, instrumenty polityki makroostrożnościowej w sektorze ubezpieczeń koncentrują się w zasadzie w dwóch wymiarach: przestrzennym i czasowym. Główny nacisk kładziony jest na ograniczenie procykliczności oraz podwyższenie zdolności do absorbcji potencjalnych strat przez systemowo ważnych ubezpieczyceli, a także - o ile to możliwe - „odkonglomeryzowanie” grup ubezpieczeniowych. Trudno obecnie mówić o wiarygodnych wskaźnikach efektywności projektowanych rozwiązań, bowiem brakuje, ze względów obiektywnych, wiarygodnych długofalowych badan. Jednakże, mając na uwadze relatywnie niski potencjał sektora ubezpieczeń do kreowania ryzyka systemowego, już na obecnym etapie można stwierdzić, że instrumentarium makroostrożnościowe powinno być ściśle powiązane z instrumentami polityki mikroostrożnościowej, która winna odgrywać wiodącą rolę. Zasadne wydaje się, zwłaszcza w Polsce, rozbudowanie infrastruktury nadzorczej i regulacyjnej w zakresie polityki mikroostrożnościowej, mającej na celu ochronę beneficjentów usług ubezpieczeniowych. W tym zakresie, na co wskazuje intensyfikacja wydawania zaleceń przez KNF oraz postępowania i kary nakładane przez UOKiK, samoregulacja rynku zawiodła. Doświadczenia innych państw, jak np. Wielkiej Brytanii, pokazują, że dobre efekty przynosi wypracowywanie rozwiązań prewencyjnych w zakresie nadzoru nad ochroną interesów konsumentów usług ubezpieczeniowych.

\section{Bibliografia}

Allocating macro-prudential powers, Reports of the Advisory Scientific Committee 2014, No. 5 2014, ESRB.

Angelini P., Nicoletti-Altimari S., Visco I., Macroprudential, Microprudential and Monetary Policies: Conflicts, Complementarities and Trade-Offs, "Occasional Papers" 2012, No. 140, Bank of Italy.

Basic Capital Requirements for Global Systemically Important Insurers, 23 October 2014. 
Borio C., Towards a Macroprudential Framework for Financial Supervision and Regulation?, "BIS Working Papers" 2003, No. 128.

Chen H., Cummins J.D., Krupa S., Viswanathan, Weiss M.A., Systemic Risk and the Interconnectedness between Banks and Insurers: an Econometric Analysis, "The Journal of Risk and Insurance" 2013, Vol. 81, No. 3.

Insurance and Financial Stability, IAIS, November 2011.

Competition and related regulation issues in the insurance industry, OECD 1998, DAFFE/CLP (98) 20.

Claessens S., An Overview of Macroprudential Policy Tools, "IMF Working Paper" 2014, No. WP/14/214.

Crockett A., Marrying the micro- and macro-prudential dimensions of financial stability, Eleventh International Conference of Banking Supervisors, BIS, Basel 2000, http:// www.bis.org/speeches/sp000921.htm

Brunnermeier M., Crocket A., Goodhart C., Persaud A., Shin H., The fundamental principals of financial regulation, $11^{\text {th }}$ Geneva Report on the World Economy, Geneva 2009.

Clement P., The term 'macroprudential': origins and evolution, "BIS Quarterly Review" 2010, March.

Czerwińska T., Ryzyko systemowe w sektorze ubezpieczeń - analiza ekspozycji w krajach Unii Europejskiej, „Problemy Zarządzania” 2014, nr 4.

Fitzpatrick J.H., Cross industry analysis 28 G-SIBs vs. 28 Insurers - Comparison of systemic risk indicators, The Geneva Association, February 2013.

Galati G., Moessner R., Macroprudential Policy - a Literature Review, "BIS Working Papers" 2011, No. 337.

Dewatripont M., J. Tirole, The Prudential Regulation of Banks, MIT Press, Cambridge 1994.

Dobrzańska A., Polityka makroostrożnościowa - zagadnienia instytucjonalne. Teoria i dotychczasowe doświadczenia w Unii Europejskiej, „Materiały i Studia” 2014, nr 307, NBP.

Dyrektywa Parlamentu Europejskiego i Rady 2009/138/WE z dnia 25 listopada 2009 r. w sprawie podejmowania i prowadzenia działalności ubezpieczeniowej i reasekuracyjnej (Wypłacalność II), Dz. U. UE z 17/12/2009.

Eling M., Pankoke D., Costs and Benefits of Insurance Regulation - An Empirical Assessment from the Industry Perspective, Institute of Insurance Economics, University of St. Gallen, $15^{\text {th }}$ July 2014.

Flagship Report on Macro-prudential Policy in the Banking Sector, European Systemic Risk Board, Frankfurt 2014.

Galati G., Moessner R., Macroprudential policy - a literature review, "BIS Working Papers" 2011, No. 337.

Giordano C., Prudential Regulation and Supervision Instruments and Aims: A General Framework, w: Financial Market Regulation in the Wake of Financial Crises: The Historical Experience, red. A. Gigliobianco, G. Toniolo, Banca d'Italia, Roma 2009. 
Hanson S.G., Kashyap A.K., Stein J.C., A macroprudential approach to financial regulation, "Journal of Economic Perspectives" 2011, No. 25(1).

Macroprudential policy: an organizing framework, IMF, Washington 2011.

Instruments of macroprudential policy, A Discussion Paper Bank of England, December 2011.

Key Attributes of Effective Resolution Regimes for Financial Institutions, FSB, October 2011.

Klein R.W., Principles for Insurance Regulation: An Evaluation of Current Practices and Potential Reforms, 31 January 2011.

Macroprudential Policy and Surveillance in Insurance, IAIS, 18 July 2013.

Macroprudential Policy Tools and Frameworks, Progress Report to G20, Financial Stability Board, International Monetary Funds, Bank for International Settlements, 27 October 2011.

Marcinkowska M., Regulation and self-regulation in banking: in search of optimum, "Bank i Kredyt" 2013, nr 2.

Olszak M., Polityka ostrożnościowa w ujęciu makro - cel, instrumenty i architektura instytucjonalna, „Problemy Zarządzania” 2012, nr 4(39).

Osiński J., Seal K., Hoogduin L., Macroprudential and Microprudential Policies: Towards Cohabitation, IMF Staff Discussion Note SDN/13/05, IMF, June 2013.

Persaud A., Macro-Prudential and Micro-Prudential Regulation, The University of Warwick 2009.

Projekt założeń do projektu Ustawy o działalności ubezpieczeniowej i reasekuracyjnej (wersja z 12 grudnia 2014) (RM-10-109-14).

Rosati D., Regulacje makroostrożnościowe a stabilność sektora bankowego, „Bank i Kredyt” 2014, $\mathrm{nr}$ 45(4).

Roubini N., Mihm S., Ekonomia kryzysu, Wolters Kluwer, Warszawa 2001.

Schmitz B., Macroprudential financial market regulation: Aims, implementation, and implications for developing and emerging economies, "Discussion Paper Deutsches Institut für Entwicklungspolitik” 2013, No. 20, Bonn.

Schoenmaker D., Kremers J., Financial stability and proper business conduct: Can supervisory structure help to achieve these objectives?, w: Institutional Structure of Financial Regulation: Theories and International Experiences, red. R. Huang, D. Schoenmaker, Routledge, London 2014.

Schoenmaker D., An Integrated Financial Framework for the Banking Union: Don't Forget Macro-Prudential Supervision, "Economic Papers" 2013, No. 495.

Systemic Risk in Insurance, An Analysis of insurance and financial stability, The Geneva Association, March 2010.

Szpunar P., Rola polityki makroostrożnościowej w zapobieganiu kryzysom finansowym, „Materiały i Studia” 2012, nr 278, NBP. 
White E.N., Lessons From The History Of Bank Examination And Supervision in the United States, 1863-2008, w: Financial Market Regulation in the Wake of Financial Crises: The Historical Experience, red. A. Gigliobianco, G. Toniolo, "Banca d'Italia" 2009, No. 1.

Zhou Ch., Why the micro-prudential regulation fails? The impact on systemic risk by imposing a capital requirement, "DNB Working Paper" 2010, No. 256.

\section{Micro- and Macroprudential Policy Instruments in the Insurance Sector}

The purpose of this study is to analyze key characteristics of micro- and macroprudential approaches to supervision regulations in the insurance sector. Analysis of micro- and macroprudential policy instruments reveal common sources but different aims of the instruments. Macroprudential instruments are used to reduce systematic risks, while microprudential instruments are used to provide liquidity and solvency. Bearing in mind the relatively low potential of the insurance sector for risk creation, it seems that macroprudential instruments should be closely connected with microprudential instruments. However, it is the microprudential instruments that need to play the key role.

Keywords: Prudential policy, insurance sector, systematic risk

\section{Les instruments de la politique micro- et macroprudentielle dans le secteur des assurances}

Le but de cette étude est d'analyser les principales caractéristiques des approches micro- et macroprudentielles aux règles de supervision dans le secteur de l'assurance. L'analyse de ces instruments révèle leurs sources communes et leurs objectifs différents. Les instruments macroprudentiels sont utilisés pour réduire les risques systématiques, tandis que les instruments microprudentiels sont utilisés pour fournir la liquidité et la solvabilité. En gardant à l'esprit le potentiel relativement faible du secteur de l'assurance pour la création du risque, il semble que les instruments macroprudentiels devraient être étroitement liés aux instruments microprudentiels. Cependant, ce sont les instruments microprudentiels qui devraient jouer un rôle clé.

Mots-clés: la politique prudentielle, le secteur de l'assurance, le risque systématique 


\section{Инструменты микро- и макропруденциальной политики в секторе страхования}

Целью данного исследования является анализ ключевых характеристик микро- и макропруденциального подходов к надзору в страховом секторе. Анализ инструментов микро- и макропруденциальной политик показывает, что у них общий источник, но разные цели. Макропруденциальные инструменты используются для уменьшения системных рисков, в то время как микропруденциальные - для обеспечения ликвидности и платежеспособности. Учитывая относительно низкий потенциал страхового сектора по созданию риска, кажется, что макропруденциальные и микропруденциальные инструменты должны быть тесно связаны. Тем не менее, микропруденциальные инструменты должны играть ключевую роль.

Ключевые слова: пруденциальная политика, страховой сектор, системный риск 